\title{
Analysis of Smoking Behavior and Stress Management in Hypertension Sufferers of Productive Age at Dr. Moedjito Dwidjosiswoyo Hospital Jombang
}

\author{
Eval Braco Athatur ${ }^{1}$, Sandu \\ Siyoto $^{2}$, Bambang Pardjianto ${ }^{3}$ \\ ${ }^{1}$ Dr. Moedjito Dwidjosiswoyo \\ Hospital, Jombang \\ ${ }^{2}$ Master Program of Public Health, \\ Institute of Health Sciences Strada \\ Indonesia \\ ${ }^{3}$ Ners Education Study Program, \\ Institute of Health Sciences Strada \\ Indonesia \\ Email: \\ evalbraco478@gmail.com
}

Received: February $16^{\text {th }} 2021$

Accepted : February $16^{\text {th }} 2021$

Published : May $20^{\text {th }} 2021$

\begin{abstract}
The high incidence of hypertension is caused by various causes including the lifestyle of the city community such as obesity, excessive salt consumption, lack of exercise, smoking. In addition, a person's lifestyle psychic condition such as stress can also affect the increase in blood pressure. Stress increases the activity of sympathetic nerves, thus raising blood pressure erratically. The purpose of the study was to analyse smoking behavior and stress management of hypertension sufferers of productive age. The design of this research is analytics with a crossectional approach. The variables of this study are smoking behaviour and stress management as independent variables as well as blood pressure as dependent variables. The study population of patients with hypertension hospital dr. Moerdjito Jombang as many as 142 patients in March 2020. Samples were taken with simple random sampling techniques as many as 105 respondents. The data was collected by questionnaire instrument and processed using editing, coding, scoring and tabulating and tested with spearman rho test. This suggests that smoking behavior and stress management in sufferers may affect
\end{abstract}

Keywords: Smoking behavior, stress management, hypertension, productive age

Copyright ( 2021 IIK STRADA Indonesia All right reserved.

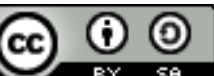

This is an open-acces article distributed under the terms of the Creative Commons Attribution-ShareAlike 4.0 International License.

\section{INTRODUCTION}

Hypertension is defined as a disease characterized by an increase in blood pressure exceeding normal. In general, systolic ranges above $140 \mathrm{mmHg}$ and diastolic above $85 \mathrm{mmHg}$ is considered to be the limit line of hypertension (Junaidi, 2010). Hypertension is the number one cause of death in the world and is increasing even longer if appropriate and appropriate treatment efforts are not carried out (Prasetyaningrum, 2014). The high incidence of hypertension is caused by various causes including the lifestyle of the city community such as obesity, excessive salt consumption, lack of exercise, smoking. In addition, a person's lifestyle psychic condition such as stress can also affect the increase in blood pressure. Stress increases the activity of sympathetic nerves, thus raising blood pressure erratically. When prolonged stress can result in high sedentary blood pressure. This indicates that hypertension sufferers cannot have a normal life like others (Purnama, 2016).

According to who in 2016 there are 712 million hypertension patients worldwide. The highest prevalence occurs in the African region at $30 \%$. The lowest prevalence is in the Americas at $18 \%$. By 
2025, who estimates that one billion people in the world suffer from hypertension. Two-thirds of them are in low- and moderate-income developing countries. Indonesia is in the top 10 countries with the highest prevalence of hypertension in the world, alongside Myanmar, India, Sri Lanka, Bhutan, Thailand, Nepal, Maldives. The prevalence of hypertension will continue to increase, and it is predicted that by 2025 as many as $29 \%$ of adults in the world will be affected by the attacks. From the data of the Indonesian Ministry of Health, in Indonesia alone the prevalence of hypertension is 31.7\%, which means that 1 in 3 people experience it. Ironically, $76 \%$ of those who did not know themselves had hypertension. Basic Health Research data 2013 shows that 25.8 percent of Indonesians have hypertension and in 2016 the National Health Indicators Survey (Sirkesnas) increased to 32.4 percent, and the results of Basic Health Research (2018) mentioned the prevalence of hypertension increased to $34.1 \%$ obtained through blood pressure measurements at age 18 and above (Kemenskes, 2018). Meanwhile, according to the Ministry of Health of East Java Province, the number of hypertension patients in 2017 amounted to $20.43 \%$ or about $1,828,669$ inhabitants, with a proportion of men at $20.83 \%$ (825,412 inhabitants) and women at $20.11 \%$ $(1,003,257$ inhabitants) and in 2018 increased to $22.71 \%$ or approximately $2,360,592$ inhabitants, with a proportion of men at $18.99 \%$ (808,009 inhabitants) and women at $18.76 \%$ (1,146,412 inhabitants).

The results of a preliminary study conducted at dr. Moedjito Dwidjosiswoyo Jombang Hospital obtained data on visits of hypertension patients in 2019 amounted to more than in 2018, which amounted to 593 patients, consisting of 183 new cases and 410 old cases of primary data. number of hypertension patients in January - February 2020 as many as 142 hypertension patients. The results of interviews with 5 hypertensive patients were obtained by all patients including aktfi smokers and a day can finish 1-2 packs of cigarettes, and they do not know how to manage stress to prevent recurrence of hypertension, and they consider cigarettes as one way to reduce stress experienced.

One of the causes of hypertension is smoking habit. Smoking is very large role to increase blood pressure, this is caused by nicotine contained in cigarettes that trigger the hormone adrenaline that causes blood pressure to increase. Nicotine is absorbed by the blood vessels in the lungs and circulated throughout the bloodstream so that there is a narrowing of the blood vessels. This causes increased heart work to pump blood throughout the body through narrow blood vessels. Cigarettes result in vasoconstriction of peripheral blood vessels and vessels in the kidneys resulting in an increase in blood pressure. Smoking a bar every day increases systolic pressure by $10-25 \mathrm{mmHg}$ and increases heart rate 520 times per minute. Smoking actively or passively basically sucks co (carbon monoxide) which has the ability to bind hemoglobin $(\mathrm{Hb})$ contained in red blood cells (erythrocytes) stronger than oxygen. Body cells suffering from oxygen deprivation will attempt to increase that through compensating blood vessels by shrinking or spasm and resulting in increased blood pressure. Cigarette smoke also contains nicotine which causes resistance to the hormone epinephrine (adrenaline) which promotes an increase in the frequency of heart rate, blood pressure, heart oxygen needs, and causes heart rhythm disorders. According to the study, the risk of smoking causing hypertension is related to the amount of cigarettes smoked per day, and not the length of smoking. A person who smokes more than one pack of cigarettes a day becomes more prone to hypertension. The chemicals in cigarettes are cumulative (stockpiled), at some point the dose of the poison will reach the point of toxication so that it begins to appear symptoms that it causes (Price, 2009).

In addition to smoking stress factors greatly influence the recurrence of hypertension, stress is an unavoidable reality of daily life, stress or emotional tension can affect the cardiovascular system, especially hypertension. Stress increases peripheral vascular resistance and cardiac bulk so that it stimulates sympathetic nerve activity (Sulastri, 2016). Hypertension will appear in people who are often stressed and experience protracted tension of the mind (Muawanah, 2012). Stress is the unavoidable reality of life. Stress or emotional tension can affect the cardiovascular system, especially hypertension. Stress is believed to increase the risk of hypertension through activation of the sympathetic nervous system resulting in an intermittent (erratic) rise in blood pressure. When a person experiences stress, the hormone adrenaline will be released and will then increase blood pressure through arterial contraction (vasocontriction) and increased heart rate. If the stress continues, blood pressure will remain high so that the person will experience hypertension (Islami, 2015). Hypertensive disease will be a serious problem if 
not treated immediately. Hypertension is a chronic disease that needs regular treatment. Controlling blood pressure regularly can prevent further consequences or complications that may occur in hypertension sufferers such as heart disease, congestive heart failure, stroke, vision impairment and kidney disease (Andria, 2013).

One of the actions that can be done by health workers is to provide health education to patients. Health education as a number of experiences that have a beneficial effect on the knowledge, attitudes and habits of hiudp daily. Health education is a planned effort to influence others whether individuals, groups, or communities so that they do what education actors expect with the aim of improving health status, preventing disease, maintaining health degrees, maximizing the function and role of sufferers during illness, and helping sufferers and families overcome health problems (Mubarak et al., 2012)

Based on this background, researchers are interested to conduct further research on "Analysis of smoking behavior and stress management of hypertension patients of productive age at dr. Moedjito Dwidjosiswoyo Jombang Hospital".

\section{RESEARCH MATERIALS AND METHODS}

The design of this research is analytics with a crossectional approach. The variables of this study are smoking behavior and stress management as independent variables as well as blood pressure as dependent variables. The study population of patients with hypertension hospital dr. Moerdjito Jombang as many as 142 patients in March 2020. Samples were taken with simple random sampling techniques as many as 105 respondents. The data was collected by questionnaire instrument and processed using editing, coding, scoring and tabulating and tested with spearman rho test. This research also get an ethical approved from Health Research Ethic Commiitee in Institute Of Health Science Strada Indonesia with the number of certificate is 2085/KEPK/VII/2020

\section{RESULT}

1. Cross tabulation between Smoking Behavior and Blood Pressure

Table 1 Cross-tabulation between smoking behavior and blood pressure at Dr. Moedjito Dwijosiswodjo Hospital in August 2020 (n=105)

\begin{tabular}{lcccccc}
\hline \multirow{2}{*}{ Smoking Behaviour } & \multicolumn{9}{c}{ Blodd Pressure } \\
\cline { 2 - 7 } & \multicolumn{2}{c}{ Uncontrolled } & \multicolumn{2}{c}{ Controlled } & \multicolumn{2}{c}{ Total } \\
\cline { 2 - 7 } & $\mathrm{f}$ & $\%$ & $\mathrm{f}$ & $\%$ & $\mathrm{f}$ & $\%$ \\
\hline Very Heavy & 14 & 87,5 & 2 & 12,5 & 16 & 100 \\
\hline Heavy & 35 & 68,6 & 16 & 31,4 & 51 & 100 \\
\hline Moderate & 3 & 17,6 & 14 & 82,4 & 17 & 100 \\
\hline Mild & 3 & 14,3 & 18 & 85,7 & 21 & 100 \\
\hline
\end{tabular}

Based on table 1, the results of cross tabulation between respondents' smoking behavior and blood pressure variables were obtained. Based on very heavy smoking behavior most of the respondents' blood pressure in the uncontrolled category was 14 respondents $(87.5 \%)$, in heavy smoking behavior most of the respondents' blood pressure in the uncontrolled category was 35 respondents $(68.6 \%)$, in moderate smoking behavior most of the respondents' blood pressure in the controlled category was 14 respondents $(82.4 \%)$. In light smoking behavior most respondents' blood pressure in the controlled category was 18 respondents $(85.7 \%)$.

2. Cross tabulation between Stress Manajemen and Blood Pressure

Table 2 Cross-tabulation between stresss manajemen and blood pressure at Dr. Moedjito Dwijosiswodjo Hospital in August 2020 (n=105)

\begin{tabular}{ccccccc}
\hline \multirow{3}{*}{ Stress Manajemen } & \multicolumn{5}{c}{ Blood Pressure } \\
\cline { 2 - 6 } & \multicolumn{2}{c}{ Uncontrolled } & Controlled & Total \\
\cline { 2 - 6 } & $\mathrm{f}$ & $\mathrm{f}$ & $\%$ & $\mathrm{f}$ & $\%$ \\
\hline
\end{tabular}




\begin{tabular}{lcccccc}
\hline Very less & 16 & 84,2 & 3 & 15,8 & 19 & 100 \\
\hline Less & 18 & 58,1 & 13 & 41,9 & 31 & 100 \\
\hline Enough & 14 & 46,7 & 16 & 53,3 & 30 & 100 \\
\hline Good & 6 & 30 & 14 & 70 & 20 & 100 \\
\hline Very Good & 1 & 20 & 4 & 80 & 5 & 100 \\
\hline
\end{tabular}

Based on table 2, the results of cross tabulation between respondents' stress management and blood pressure variables were obtained. Based on stress management is very lacking most of the blood pressure of respondents in the uncontrolled category as many as 16 respondents $(84.2 \%)$, in stress management is less most of the blood pressure of respondents in the uncontrolled category as much as 18 respondents $(58.1 \%)$, in stress management that is quite mostly the blood pressure of respondents in the uncontrolled category as many as 14 respondents (46.7\%). In stress management, most of the respondents' blood pressure in the controlled category was 14 respondents $(70 \%)$ and in excellent stress management some respondents' blood pressure in the controlled category as much as 4 respondents $(80 \%)$.

\section{Bivariat Analysis}

Table 3 Bivariate Analysis between Stress Management and smoking behavior with blood pressure at Dr. Moedjito Dwijosiswodjo Hospital in August 2020 (n=105)

\begin{tabular}{lllll}
\hline No & Independen Variable & Dependen Variable & $\boldsymbol{\rho}$ value & Corelation Coefficient \\
\hline 1 & Stress Manajemen & Blood Pressure & 0,000 & 0,548 \\
\hline 2 & Smoking Behaviour & Blood Pressure & 0,000 & 0,650 \\
\hline
\end{tabular}

Based on table 3 showed the results of bivaiat analysis test using spearman rho test showed that the value of $\rho$ value of both independent variables (stress management and smoking behavior) is $<0.05$ so that the results of this study showed there is a relationship between stress management and smoking behavior with respondents' blood pressure. Based on the correlation coefficient value shows that the correlation coefficient value between stress management and blood pressure is obtained a value of 0.548 , this indicates that stress management has a moderate correlation. The coefficient of smoking behavior correlation with blood pressure was obtained a value of 0.650 , this indicates that smoking behavior has a high correlation.

\section{DISCCUSSION}

A. Smoking behavior of hypertension sufferers of productive age in hospital dr. Moedjito Dwidjosiswoyo Jombang.

Based on the results of the study obtained data most respondents fall into the category of heavy smokers as many as 51 respondents (49\%) and a small percentage including very heavy smokers as many as 16 respondents (15\%)

The results of this study are in accordance with muhith research (2012) on hypertensive patients obtained data that respondents in Klaten Islamic Hospital as much as $67 \%$ smoke more than 10 cigarettes every day, as many as $63 \%$ smoke with non-filter cigarettes, as many as $82 \%$ have smoked more than 10 years, as much as $55 \%$ smoke by means of in. The conclusion of this study is that hypertensive patients mostly have a habit of smoking more than 10 cigarettes every day, smoking with non-filtered cigarettes, smoking more than 10 years and smoking by suction in.

Smoking is a behavior that is harmful to health, but there are still many people who do it even people start smoking when they are teenagers. Habit is a behavior that we often repeat either intentionally and behavior or habits that we have done since childhood until adulthood (Irfan, 2008). Smoking behavior of a person's activity which is the person's response to external stimuli are factors that influence a person to smoke and can be observed directly (Suparyanto, 2011). One of the reasons 
why consumers continue to buy certain products is because consumers do not want to be difficult in making decisions. Consumer satisfaction factor also affects, if consumers are satisfied, then consumers will decide to re-purchase certain products (Hawkin, 2004,). They are said to be very heavy smokers, is when consuming more than $>12$ cigarettes per day. While heavy smokers smoke about 7-12 cigarettes / day, smokers are spending 4-6 cigarettes while light smokers spend about 1-3 rods (Aditama,2009).

The results of this study showed that most respondents belonged to heavy category smokers. This happened because respondents felt that with them consuming cigarettes they could find newer ideas and atmospheres and stop boredom at work and in hanging out so that they should consume cigarettes even though respondents knew the negative impact of the cigarettes they smoked. The respondent's behavior was influenced by several factors including age, education and occupation of respondents.

Based on the age of respondents obtained data from cross tabulation between the characteristics of respondents and smoking behavior, namely based on the age of respondents obtained data from 3 respondents aged 26-35 years mostly fall into the category of heavy smokers as much as 2 respondents $(66.7 \%)$ and of the 48 respondents aged $36-45$ years, most of them fall into the category of heavy smokers as many as 22 respondents $(45.8 \%)$. Of the 32 respondents aged 46-55 years, most were included in the heavy category smokers as many as 17 respondents $(53.1 \%)$ and in 33 respondents aged 56-64 years, most of them fall into the category of heavy smokers as many as 10 respondents $(45.5 \%)$. Habits are influenced by 3 factors, namely environmental factors. Environment or residence (e.g. home) affects us in activities that eventually form a habit. age factor. Although this is not a deciding factor, age can affect a person's habits. Experience in socializing or socializing. If a person has good emotional maturity, then a good person will be formed who can adjust to the local environment, so that wherever we are there can be harmonious in association with the community that affects our behavior in society that leads to habits (Afza, 2012). Based on the age of this study, most respondents are $>30$ years old at this age they have been able to make decisions based on their own strength but because of the influence of association makes respondents spend more than 12 cigarettes in a day.

Based on the education of respondents obtained data from 10 respondents who are graduates of elementary education (SD, SLTP) mostly fall into the category of smokers berta as much as 5 respondents $950 \%$ ). And of the 58 respondents who are graduates of secondary education (SLTA, MAN) most fall into the category of heavy smokers as many as 30 respondents (51.7\%). And of the 37 respondents who are graduates of higher education, most fall into the category of heavy smokers as many as 16 respondents (43.2\%). The level of education of patients can increase knowledge and archery in preventing the occurrence of hypertension, as long as that the education is an active education that is obtained independently, through certain stages. The older a person is, the process of mental development increases, but at certain ages, the process of mental development is not as fast as when in his teens, thus it can be concluded that the age factor will affect the level of knowledge of a person who will peak at a certain age and will decrease the ability to receive or remember something as he gets older. This is supported by a low level of education (Potter and Perry, 2011). The education of respondents in this study included secondary education, with which respondents were able to understand about what should or should not be consumed by hypertensive patients. With these insights, respondents tried to follow the advice of health workers in reducing cigarettes smoked.

\section{B. Stress manajemen of hypertension sufferers of productive age in hospital dr. Moedjito Dwidjosiswoyo Jombang.}

Based on the results of research on stress management shows that most hypertension patients fall into the category of lack of stress management as many as 30 respondents (29\%) and a small percentage are included in the excellent kateogri as many as 5 respondents $(5 \%)$.

According to Herdianti (2013) Stress management is looking for the most suitable way to reduce stress. Stress management can be done by processing stress, regulating emotions, receiving 
stressors, and maintaining nutrient intake. According to Riskha (2012) defines stress management as a skill that allows a person to anticipate, prevent, manage, and recover from the stress felt due to threats and incompetence in coping. Carlson, et al., (2010) mentions to do stress management, the individual needs to understand himself, namely understanding the cause or source of stress as well as what actions suit his condition.

Stress management of respondents in the category is less because respoden still do not know how effective to manage or manage the stress faced by respondents so that respondents are still not able to manage or manage stress well. This is seen from the statement of respondents at the time of the study, some respondents said stress due to physical changes in him, easily tired, and the loss of people closest to the husband / wife, biological children. And when viewed from the questionnaire, respondents often have difficulty resting, anxiety, irritability, sometimes anger because of small things / spele, tend to overreact to a situation, easily anxious and difficult to be patient. In addition, everyone has different physical and psychological backgrounds and conditions, so everyone needs to understand the need for him/her in order to face stressors in his own way.

Based on cross tabulation between respondent characteristics and stress management variables. Based on the work of respondents obtained data from 27 respondents who did not work mostly in the category of good enough in conducting stress management as many as 10 respondents (37\%) and of the 78 respondents who worked mostly classified as poor in stress management as many as 28 respondents $(35.9 \%)$.

The diversity of stress levels is caused by factors that influence the effects of stressors on different individuals. Moderate stress levels that are if last longer, from a few hours even to a few days and moderate stress can also trigger the occurrence of diseases. Stressors that can cause moderate stress are unfinished agreements, excessive workload (Azizah, 2016).

Daily activities carried out by respondents are more silent at home such as watching television, cleaning the house and cooking. Work is very influential on a person's physical activity because usually people who do not work can increase boredom and boredom if the activities carried out monotonously every day, as well as can be the incidence of physical hypertension, especially in cardiovascular.

\section{Blood Pressure of hypertension sufferers of productive age in hospital dr. Moedjito Dwidjosiswoyo Jombang.}

Based on the results of blood pressure measurements showed that some blood pressure of hypertension patients in the category of uncontrolled as many as 55 respondents $(52 \% 0$ and a small percentage in the uncontrolled category of 50 respondents (48\%).

Hypertension or high blood pressure disease is a disorder of the blood vessels that results in the supply of oxygen and nutrients, carried by the blood, inhibited to the tissues of the body in need. Hypertension is often referred to as a silent killer, because it includes a deadly disease without being accompanied by its symptoms first as a warning to its victims (Sustrani, 2015).

The mechanism of hypertension is through the formation of angiostensin II of angiostensin I by Angiostensin I Converting Enzyme (ACE). ACE plays an important physiological role in regulating blood pressure. Blood contains angiostensinogen produced in the liver. Furthermore by hormones, renin (produced by the kidneys) will be converted into angiostensin I. by ACE found in the lungs, angiostensin I is converted into angiostensin II. Angiostensin II has a key role in raising blood pressure through two main actions. Pathogenesis of essential hypertension is multifactorial and very complex. These factors alter the function of blood pressure to strong tissue perfusion including hormone mediator, vascular exercise, blood circulation volume, vascular caliber, blood viscosity, cardiac bulk, elasticity of blood vessels and neural stimulation. Pathogenesis of essential hypertension can be triggered by several factors including genetic factors, salt intake in the diet, stress levels can interact to give rise to hypertensive symptoms. 


\section{Relationship of smoking behavior with blood pressure of hypertension sufferers of productive age at dr. Moedjito Dwidjosiswoyo Jombang Hospital}

Based on table 1, the results of cross tabulation between respondents' smoking behavior and blood pressure variables were obtained. Based on very heavy smoking behavior most of the respondents' blood pressure in the uncontrolled category was 14 respondents $(87.5 \%)$, in heavy smoking behavior most of the respondents' blood pressure in the uncontrolled category was 35 respondents $(68.6 \%)$, in moderate smoking behavior most of the respondents' blood pressure in the controlled category was 14 respondents $(82.4 \%)$. In light smoking behavior most respondents' blood pressure in the controlled category was 18 respondents $(85.7 \%)$.

Based on table 3 showed the results of bivaiat analysis test using spearman rho test showed that the value of independent variable (smoking behavior) is $<0.05$ so that the results of this study showed there is a relationship between smoking behavior and blood pressure of respondents. By. The coefficient of smoking behavior correlation with blood pressure was obtained a value of 0.650 , this indicates that smoking behavior has a high correlation.

Cigarettes are also associated with hypertension. The relationship between cigarettes and increased cardiovascular risk has been widely proven. Aside from the length of time, the greatest risk of smoking depends on the amount of cigarettes smoked per day. More than one pack of cigarettes a day is twice as prone to hypertension than those who do not smoke. Toxic chemicals, such as nicotine and carbon monoxide smoked through cigarettes, which enter the bloodstream can damage the endothelial lining of arterial blood vessels and result in atherosclerosis and hypertension processes. Nicotine in tobacco is the cause of increased blood pressure after the first suction. Like other chemicals in cigarette smoke, nicotine is absorbed by very small blood vessels in the lungs and circulated into the bloodstream. In just a few seconds the nicotine has reached the brain. The brain reacts to nicotine by signaling the adrenal glands to release epinephrine (adrenaline) (Sugiharto, 2009). The chemicals in cigarettes are cumulative, so that heavy smokers who smoke more than 10 cigarettes every day will receive faster impacts caused by cigarettes compared to light smokers who smoke less than 10 cigarettes per day. So that the more jumah cigarettes are smoked, the more toxic substances that enter the body that can increase the incidence of hypertension (Sunyoto, 2012). The results of this study are in accordance with Laksono's research (2013) which showed that in patients who have smoking behavior, most experience recurrence in the frequent category of 14 respondents (93\%) while in patients who did not have smoking behavior most experienced a relapse.

The results of this study showed that respondents' smoking behavior contributed to increasing respondents' blood pressure. Because there is a content of cigarettes that are sucked affects blood pressure becomes uncontrolled, and the more cigarettes are smoked the faster there will be a rise in blood pressure. This happens because respondents are already aware of the impact, but the influence of the environment or lifestyle causes respondents to be reluctant to stop or reduce the smoking habit.

\section{E. Relationship of Stress manajemen with blood pressure of hypertension sufferers of productive age at dr. Moedjito Dwidjosiswoyo Jombang Hospital}

Based on table 2, the results of cross tabulation between respondents' stress management and blood pressure variables were obtained. Based on stress management is very lacking most of the blood pressure of respondents in the uncontrolled category as many as 16 respondents $(84.2 \%)$, in stress management is less most of the blood pressure of respondents in the uncontrolled category as much as 18 respondents $(58.1 \%)$, in stress management that is quite mostly the blood pressure of respondents in the uncontrolled category as many as 14 respondents (46.7\%). In stress management, most of the respondents' blood pressure in the controlled category was 14 respondents $(70 \%)$ and in excellent stress management some of the respondents' blood pressure in the controlled category as many as 4 respondents $(80 \%)$

Based on table 3 showed the results of bivaiat analysis test using spearman rho test showed that the value of independent variable (stress management) is $<0.05$ so that the results of this study showed there is a relationship between stress management and blood pressure of respondents. 
Based on the correlation coefficient value shows that the correlation coefficient value between stress management and blood pressure is obtained a value of 0.548 , this indicates that stress management has a moderate correlation.

The results of this study are in line with research conducted by Afiah (2018) which states that stress is one of the risk factors for hypertension. In this study states that the level of stress with blood pressure that occurs is suspected through the activity of sympathetic nerves, which can increase the pressure gradually. Stress or mental tension

i.e. feeling depressed, moody, confused, anxious, irritable, fear and guilt that can spur the heart to beat faster and stronger, so that blood pressure increases. Wedri (2017) states that constant and persistent stress can affect

the work of the adrenal glands and teroids in producing hormones. Adrenaline, tyroxine and cortisol are the main stress hormones. Adrenaline that works synergistically with the sympathetic nervous system affects the increase in heart rate and blood pressure.

The results of this study illustrate that when stress levels increase and hypertension sufferers are unable to control management or management of stress then indirectly blood pressure also increases or the occurrence of relapse and vice versa. Respondents' knowledge affects the ability to do stress management so that respondents can prevent the occurrence of increased blood pressure quite well. This indicates that each person's stress reactions differ depending on how the individual is dealing with or dealing with the stress experienced so as to prevent a rise in blood pressure or be able to control blood pressure better.

\section{CONCLUTION}

1. Smoking habits of hypertension sufferers of productive age in The Poly Of Internist at Dr. Moedjito Dwijosiswodjo Hospital most of the respondents belonged to the category of heavy smokers as many as 51 respondents $(49 \%)$

2. Stress management of hypertension patients of productive age in The Poly Of Internist at Dr. Moedjito Dwijosiswodjo Hospital most hypertension sufferers fall into the category of lack of stress management as many as 30 respondents (29\%)

3. Blood pressure of hypertension patients of productive age in Poly Of Internist at Dr. Moedjito Dwijosiswodjo Hospital some blood pressure of hypertension patients in the category of uncontrolled as many as 55 respondents $(52 \%)$

4. There is a relationship between smoking behavior and blood pressure of hypertension patients of productive age in dr. Moedjito Dwidjosiswoyo Jombang Hospital

5. There is a relationship between stress management and blood pressure of hypertension patients of productive age in dr. Moedjito Dwidjosiswoyo Jombang Hospital

\section{SUGGESTED}

1. For Hospital Management

Should be more active in conducting health promotion activities in hypertension patients and families, especially about the prevention of hypertension so as to provide better health services and can improve the understanding of patients about the prevention and management of hypertension so that the family always reminds the sufferer to be able to reduce the consumption of cigarettes so as not to overdo it and can also help hypertension sufferers in managing the stress faced

2. For Respondents And Families

It is recommended that respondents can reduce bad smoking habits and increase knowledge about stress management and also the family is expected to motivate hypertensive patients such as reminding patients to avoid consuming too much cigarettes so that the sufferer can control his blood pressure

3. For Further Research (Science And Technology)

For further research can be used as a reference for basic materials pelitian or conduct other researchers such as factors that affect smoking habits and stress hypertension patients so that the 
results of the study can be more helpful in the development of health sciences, especially about hypertension problems.

\title{
CONFLICT OF INTEREST
}

No potential conflict of interest was reported by authors. All of research funding are from the research themselves

\begin{abstract}
AKCNOWLEDGEMENT
The author would like thank to Allah SWT, to my husband, children, parents, and my beloved sister who have provided good moral and material support so far so that I was able to complete this thesis. Furthermore, thanks and highest appreciation to this thesis supervisor Prof. Dr. Sandu Siyoto, S.Sos., S.KM., M.Kes, who provided guidance, corrections, and suggestions for the realization of this thesis. And also as the rector of IIK STRADA Indonesia Kediri, the lecturers who examined the proposal and thesis, all lecturers and staff of IIK STRADA Indonesia Kediri, head and all staff of Dr. Moedjito Dwijosiswodjo Hospital of Jombang, friends of IIK STRADA Indonesia Kediri students, and all parties who have helped the smooth writing of this thesis which cannot be mentioned one by one.
\end{abstract}

\section{REFERENCE}

Aditama. 2009. Rokok dan kesehatan, Edisi 3. Jakarta: Universitas Indonesia

Afiah, W. 2018. Faktor Resiko antara Aktivitas Fisik, Olaharaga, Obesitas dan Stres Dengan Kejadian Penyakit Hipertensi Pada Umur 45-55 Tahun Di wilayah Kerja Puskesmas Soropia Kabupaten Konawe. Fakultas Kesehatan Masyarakat Universitas Halu Oleo. Jurnal Ilimiah Kesehatan Masyarakat Vol 3 No 2

Andria, K.M. 2013. Hubungan antara perilaku olahraga, stress dan pola makan dengan tingkat hipertensi pada lanjut usia di Posyandu Lansia Kelurahan Gebang Putih Kecamatan, Sukolilo Kota Surabaya. Jurnal Promkes. 1 (2), 111-117.

Azizah, R. 2016. Hubungan Antara Tingkat Stres Dengan Kualitas Hidup Lansia Hipertensi Di Wilayah Kerja Puskesmas Wonopringgo Pekalongan. Jurnal Keperawatan Vol 5 No 1

Carlson, R., Army Career \& Alumni Program, Ayala, S., FM, Hooah 4 Health, National Institute of Mental Health. 2010. Stress management. Section 4.

Herdianti. N.S. 2013. Hubungan manajemen stres pada remaja dengan frekuensi olahraga di universitas muhammadiyah yogyakarta. Jurnal Kesehatan Masyarakat vol. 8.

Irfan Muhammad. 2008. Gambaran Pengetahuan Dan Sikap Siswa SLTP Dharma Pancasila Medan Tentang Rokok dan Iklan Rokok. Jurnal Kedokteran USU Vol.2 No 3

Islami KI. 2015. Hubungan Antara Stres Dengan Hipertensi Pada Pasien Rawat Jalan di Puskesmas Rapak Mahang Kabupaten Kutai Kartanegara Provinsi Kalimantan Timur. Jurnal Keperawatan Surakarta Vol. 2 No 32015

Junaidi, Iskandar., 2010. Hipertensi Pengenalan, Pencegahan, dan Pengobatan. Jakarta : PT Bhuana Ilmu Populer

Kementrian Kesehatan. 2018. Profil Kesehatan Indonesia Tahun 2018. Jakarta : Kemenkes RI Muawanah, 2012. Hubungan Tingkat Pengetahuan tentang Manajemen Stres Terhadap Tingkat Kekambuhan Pada Penderita Hipertensi di Panti Wreda Dharma Bakti Surakarta.

Mubarak. 2012. Promosi Kesehatan sebuah Pengantar Proses Belajar Mengajar dalam Pendidikan. Yogyakarta : Graha Ilmu

Potter, A., \& Perry. A.G. 2011. Buku ajar fundamental keperawatan: konsep, proses, praktik. Jakarta: EGC.

Prasetyaningrum, Y.N. 2014. Hipertensi Bukan Untuk Ditakuti. Jakarta : Fmedia

Price, SA, Wilson, LM. 2009. Buku Saku Patofisiologi. Ed.3. Jakarta: EGC 
Purnama. 2016. Pengaruh Program Edukasi Berbasis Komunitas terhadap Self-Management Lansia Hipertensi di Puskesmas Gombong 2 Kebumen. Bandung: Tesis Program Studi Magister Keperawatan Program Pasca Sarjana Fakultas Keperawatan Universitas Padjadjaran

Riskha. 2012. Manajemen Stres Kerja Pada Beberapa Karyawan dan Buruh Di PT. Monier Tangerang. Jurnal Studi Terapan Peminatan Psikologi Terapan Kesehatan. Volume 1 (hlm 24-110).

Sugiharto A. 2009. Faktor-Faktor Resiko Hipertensi Grade II Pada Masyarakat. Jurnal Kesmas Vol. 2 No 3

Sulastri, S. 2016. Hubungan antara Stres dan Riwayat Kontrol dengan Kekambuhan Hipertensi pada Lansia di UPTD PSLU Natar Lampung Selatan. Jurnal Kesehatan, 6(2)

Suparyanto. 2011. Rokok Dan Perilaku Merokok. Artikel Ilmiah

Sustrani. L, dkk. 2015. Hipertensi. Jakarta: Gramedia Pustaka Utama.

Wedri.2017. Stres Pada Pasien Hipertensi. Ilmu Keperawatan Politeknik Kesehatan Denpasar. Jurnal Gema Keperawatan Vol 10 No 2. 